metrical sexual orifices. The orange-coloured matter surrounding these orifices in Patella, and their position close to the mass of the salivary gland, is somewhat inexplicable, unless it should appear that part of the salivary gland is an accessory generative gland.

I have been induced to offer this abstract before proceeding to publish a fuller account, with drawings, as there may be a delay of some time in this; at the same time an opportunity may be obtained of correcting or adding to some of these notes.

XLIV.-On the Structure of the Annelida; including a critical Examination of the most recent Works on this class of Worms. By E. Claparède*.

A sosourn of five or six months at Naples, during the winter of 1866-67, enabled me to devote myself persistently to the study of the Annelida of its bay. The extraordinary richness of this sea surrounded me with an abundance of materials so great that I could not make use of the whole ; and from the very first day I was convinced how erroneous is the opinion of M. Quatrefages † that volcanic shores are poor in Annelida. The poverty which has been detected here and there by that naturalist was certainly due to other causes than vulcanicity.

The Annelida of Naples have been on the whole but little investigated. They have, however, been more studied than is generally supposed. Delle Chiaje, with his indefatigable spirit of investigation, devoted to them many hours of observation. He has accumulated drawings upon drawings, often without taking the trouble to append to them any corresponding text. His publications were made with but little method or continuity. Moreover Delle Chiaje has been but little understood, and often misunderstood $\ddagger$. His works are inexhaustible quarries, from which the roughly squared blocks will only be slowly extracted. How many times have I thought myself in a position to publish entirely new facts, only to convince myself, by the careful exa-

* From the 'Bibliothèque Universelle, Archives des Sciences,' September 1867, pp. 1-44. Communicated by the author. Translated by W. S. Dallas, F.L.S.

This memoir forms part of the introduction to a work on the Annelida of the Bay of Naples, to be published under the auspices of the Société de Physique et d'Histoire Naturelle de Genève. This work, which is now in the press, will be accompanied by thirty-one plates in 4 to.

† Histoire Naturelle des Annelés, tome i. p. 153.

¥ Delle Chiaje himself complains of having been misunderstood by Carus, Meckel, Wagner, Milne-Edwards, and Grube (Descrizione e Notomia, \&G., 1841, tome iii. p. 69). Now-a-days he might still further enlarge this list.

Ann.\& Mag. N. Hist. Ser. 3. Vol. xx. 
mination of the figures of my illustrious predecessor, that these facts were perfectly familiar to him*. Thus in every page, in the course of this memoir, I shall have to bring Delle Chiaje out of the undeserved obscurity in which he has too often remained immersed, and to show him shining in the first rank. I hope I shall not be accused of partiality in his favour. If I often leave his errors, which I admit are numerous, in oblivion, it is because they have no influence on the progress of science.

The circumstances under which I undertook the present researches were eminently favourable. Science had just been enriched by two important works relating to the Annelida-one by M. Ehlers, the other by M. Quatrefages. Both of them professed more or less to represent the actual condition of our knowledge. Aided by this double compendium, I could advance with much more certainty upon a road which had been rendered easy.

I do not conceal from myself how much I am indebted to the authors of these works for trouble avoided, for facilitated investigation $\dagger$, for the sapping of errors even before their birth. Nevertheless, without injustice towards them, I may be allowed to say that the compendium has not always performed what it seemed to promise.

The work of M. Ehlers, of which only one part (including the

* At the moment I shall only cite an example taken from beyond the limits of the subject with which I am at present occupied. A fine Dendrocele Turbellarian, Thysanozoon tuberculatum (Planaria tuberculata, Delle Chiaje, Thysanozoon Diesingii, Grube) is found in abundance in the Bay of Naples. In studying this animal, I was struck by various anatomical peculiarities, but especially by the following one:-The male apparatus is formed of two perfectly distinct halves. There exist two penises opening outwards, each separately, in the anterior part of the body, in front of the female pore. Dendrocœla were already known with a single sexual orifice, and others with two; but here was one with three apertures. This exceptional fact naturally struck me. But what was my surprise, on turning over the works of Delle Chiaje, to find a figure, without explanation, without text, without even a name at the bottom of the page, representing beyond any doubt a portion of the ventral surface of T.tuberculatum, and indicating very exactly the three sexual pores (see Descr. e Notomia degli Animali senza Vertebre, tab. 109. fig. 19. The male pores bear the letter $d$, and the female pore the letter $r$ ). This figure has slumbered since the year 1841, unknown to anybody. Delle Chiaje has inscribed at the head of one of his works the motto "Res non verba." He has been faithful to it, perhaps even too faithful.

+ In connexion with this, however, it is impossible for me not to point out a defect in the work of M. Quatrefages, which, no doubt, is not to be ascribed to its author. I mean the number of false citations. The quantity of typographical errors in the indication of volumes, pages, plates, and figures exceeds anything that could be imagined, and deprives the work of one of the merits which ought to have led to its most frequent consultation. Nowhere would exactitude have been more desirable than in this sort of dictionary of science. 
order Nereidea) has appeared, has nothing general except its title. It contains in reality a series of monographs devoted to certain species found in the Adriatic. These monographs are combined into a sort of whole by taxonomic considerations. There is nothing deserving the name of a 'Treatise on Annelida ;' the number of types investigated by the author is too small for this. Nevertheless M. Ehlers's monographs are models of exactitude. Whenever I have had the opportunity of repeating the observations of this anatomist, I have been obliged to admit their perfect truthfulness, even in details of secondary importance.

The 'Histoire Naturelle des Annelés' of M. de Quatrefages corresponds better with its title. It is a real treatise on the Annelida Polychrta. The author has set before him two objects :-in the first place, a natural classification founded on anatomy; and then an enumeration of all names and synonyms, in order to enable any one to find more easily the numerous memoirs and passages relating to Annelida which are now-a-days disseminated pretty nearly everywhere. The author has devoted long-continued attention and assiduous and prolonged labour to this rather dry work, the fruits of which will chiefly be gathered by others. No doubt this immense compilation presents some gaps or omissions, several of which will be indicated in the present memoir ; but it could hardly have been otherwise, considering the labyrinth through which the author had to find his way. The clue which the 'Histoire des Annelés' places in our hands will be henceforward a guide which cannot be disdained. This guide, indeed, must not be employed without a check. The author has often consulted plates without taking the trouble to read the corresponding text. The imperfection of a figure, or a slip of the graver, has often led him into serious mistakes. Thus, in his family Nerinea, M. de Quatrefages characterizes the worms of the genus Pygospio (Clap.) by the sole circumstance of their having uniramous feet, in opposition to all the rest of the family, in which the feet are biramous *. It is only necessary to open the volume in which I established the genus $P y$ gospio t to see that I indicate the feet as biramous, and that I describe in detail each ramus and the setæ which it bears. M. de Quatrefages, neglecting to read the text, has, no doubt established his false diagnosis from a figure on a small scale which accompanies my memoir, in which the dorsal ramus covers the ventral one, and scarcely allows it to be seen. The following is another perfectly similar example. Under the name of Lumbri-

* Hist. Nat. des Annelés, tome i. p. 437.

† Beobacht. über Anat. und Entw. wirbelloser Thiere an der Küste der Normandie angestellt. Leipzig, 1863, p. 37. 
conereis Edwardsii, I have described* a Eunicean from the shores of Normandy, which M. de Quatrefages refers to the genus Notocirrus $\dagger$, distinguished from Lumbriconereis by the existence of a dorsal cirrus on each foot. Now the Annelide in question has the feet of a true Lumbriconereis ; and I have nowhere described or figured a dorsal cirrus. Here, also, the mistake of M. de Quatrefages arises from his having neglected the text, and attended only to the plate. In this, by a mistake of the the engraver, the foot is represented reversed; and the little terminal ligulet which occurs in all species of Lumbriconereis must, no donbt, have been taken, in this position, by the French zoologist for the dorsal cirrus of a Notocirrus. Nevertheless a little care ought to have led to the recognition of the reversal of position, especially by M. de Quatrefages, who has not allowed himself to be led into error by the plates of Audouin and MilneEdwards, in which the feet of Lumbriconereis are also represented reversed.

I have cited these two examples because they concern myself; but I have not been worse treated than many others, and I shall too frequently have to point out analogous mistakes in the course of this memoir. Nevertheless I repeat, with a little circumspection, the 'Histoire des Annelés' might be employed as a very useful guide.

On the other hand, I cannot admit that the 'Histoire des Annelés' represents the present state of science from an anatomical and physiological point of view. We owe to M. de Quatrefages a multitude of important observations upon this subject. No one has studied the Annelida so persistently as he; no one, especially, has had under his hands so great a number of types, or studied them from such varied points of view. Elsewhere I have already paid, in the most formal manner, my tribute of admiration to these investigations $\ddagger$. Unfortunately, in the strength of his own numerous and profound researches, the author of the 'Histoire Naturelle des Annelés' has too often forgotten that he had predecessors, and that some of his contemporaries were exploring with ardour the same field as himself. No doubt, in a work which is only an epitome of science, history cannot occupy a great space, and the author is obliged to place himself in an entirely objective point of view. But this is not what M. de Quatrefages has done, whose personality is always put forward, even in the narration of facts known twenty or thirty years before the first scientific efforts of the author. Hence

* Beobacht. \&c. p. 58.

† Hist. Nat. des Annelés, tome i. p. 376.

+ See 'Glanures zootomiques parmi les Annélides de Port Vendres.' Geneva, 1864. 
results an actual falsification of scientific history, an unconscious falsification, no doubt, but one which we must nevertheless regret. If, in the course of this memoir, I often refer to the labours of old observers, this is partly as a protest against the ostracism with which they are beginning to be treated.

However, if M. de Quatrefages has frequently thought that he could dispense with the observations of his predecessors and contemporaries, it is to his own detriment. How many errors which I shall have to combat would have been avoided if the author had conscientiously studied the works of Rathke, Delle Chiaje, Grube, and many others, if he had taken count of the investigations of histologists such as Kölliker, Leydig, \&c. He would not then, as has sometimes occurred to him (with regard to the structure of the branchiæ, for example), have made science retrograde to the period of Pallas.

This judgment may appear severe, but it will be amply justified. Nor do I think that the greatness of the work interdicts one from indicating its defects; moreover that just pointed out could not be concealed. There is a second upon which I cannot keep silence. Why has M. de Quatrefages, whose knowledge of the Annelida is so admirable, permitted himself to be induced to describe so many genera and species from individuals preserved in spirits in the Paris Museum? He knows better than any one else that this kind of work is positively useless, and that the Annelida can only be well studied at the seaside and by means of living individuals. To describe as he has done so many alcoholic varieties is to embarrass science with a caput mortuum which will require many years to get rid of $*$.

I shall follow step by step in these pages the introduction to the 'Histoire Naturelle des Annelés,' but neither to reedit it nor to criticise it in the style of a Zoilus. But if it is useless to go over a multitude of facts which are established in it definitively, I wish, nevertheless, to dwell upon some points in which I cannot agree with the author. I also wish to recall many old observations which ought not to be forgotten. In a general way I adopt the terminology of M. de Quatrefages; and when I depart from it, it is not without indicating my reasons.

\section{Regions of the Body and Appendages.}

After much discussion as to the equivalence of the external parts of the body in Annelida, most recent authors have adopted the nomenclature of M. Grube, who gives the name of " buccal segment" to the segment which bears the mouth, and that of

* A very competent judge, Prof. Schjödte, of Copenhagen, said to me only a few days ago, "The museums press heavily upon science"-a phrase only too true in many cases. 
"cephalic lobe" (prastomium, Huxley) to everything situated in advance of it. I adopt this view, which has the advantage of not attempting to solve the question, still undecided in many cases (Glycera, Nemodrilus, \&c.), of the number of segments composing the cephalic lobe. Moreover the buccal segment is often so similar to those which follow it that it is hardly possible to refer it to a different region. M. de Quatrefages, taking up an opinion already maintained by Rathke*, regards the cephalic lobe and buccal segment as together forming the head; but he does not himself adhere too rigidly to this opinion, since in his descriptions he most frequently gives the name of head to the cephalic lobe alone.

M. de Quatrefages has endeavoured to introduce a simplification in the nomenclature of the appendages of the cephalic region, by giving the name of antenna to all the appendages which spring from the cephalic lobe, that of tentacles to all those of the buccal segment, and that of tentacular cirri to those of the first feet, when they display characters which distinguish them in a marked manner from their homologues belonging to the feet placed further back. This nomenclature, which seems well chosen at the first glance, nevertheless presents many inconveniences, and is often specifically inapplicable. In the first place, the appendages of the cephalic lobe sometimes differ entirely among themselves both as regards function and structure, which has led most authors to give them different names. What a difference there is, in particular, between the palpi (antennes latérales, Aud. \& Edw., Quatref.) and the frontal antennæ of the Lycoridea! - the former fleshy, multiarticulate, partially retractile, and occupied by the expansion of the largest nerve of the body; the latter filiform, simple, not retractile, and scantily provided with nerves. What a distance there is likewise between the palpi (Kinberg and all recent authors) and the true anteunæ in the Aphroditea! So true is this, that M. de Quatrefages has not been able to remain faithful to his principle in all cases. Thus, in the Syllidea, he retains the name of frontal lobes for organs evidently homologous with the palpi of the Lycoridea, and which ought, consequently, in his nomenclature to bear the name of antenna. This homology was demonstrated by Rathke; and no one, so far as I know, has yet contested it. It is true that M. de Quatrefages is not always consistent in his inconsistency; for when in certain Syllidea the palpi become elongated, he restores to them the name of antenna $\dagger$.

* De Bopyro et Nereide, commentationes anatomico-physiologicæ duæ. Riga et Dorpat, 1837, p. 26.

$\uparrow$ He restores it to them even with usury; for in the Polybostrichi he regards the two palpi bifurcated at the extremity as four antennæ. 
A second inconvenience of the nomenclature of M. de Quatrefages is that it is inapplicable in all those cases in which the anterior segments are much condensed, and in which it is no longer possible to determine to what segment a given pair of appendages belongs. We shall see, for example, that in the Phyllodocea and the Hesionea authors are unable to agree upon this determination, and that $\mathrm{M}$. de Quatrefages allows himself to be led away by his theory of the appendages to establish genera which no one will adopt. We also find the learned Academician, for love of his theory, suppressing by a stroke of his pen the buccal segment in most of the Sigalionida, or at least attributing to them "an indistinct buccal segment, destitute of appendages." But nothing is more distinct than the buccal segment of these Annelida; only it bears a pair of feet with setæ, which a buccal segment ought never to do, according to the theory of M. de Quatrefages. Unfortunately the author does not suspect that all the Polynoa likewise bear some setæ on the segment which he regards as the buccal ring, and that it would consequently be necessary to imagine in them an "indistinct buccal segment without appendages."

M. de Quatrefages, however, gives us a rule (difficult of application indeed, but still a rule) for the determination of the segments and their appendages. The cephalic lobe and the antennæ, he says, receive their nerves from the cerebral ganglion, the buccal segment and its tentacles from the œesophageal connectives, and the tentacular cirri from the ventral ganglionic chain. This thesis is not tenable in presence of the modern progress of embryology. Schaum asserted that in all Articulata a segment is characterized by the presence of a ganglion, and he started from this principle in denying that the head in Arthropoda is formed of several segments amalgamated together. This doctrine was immediately refuted. In fact, the nervous system is comparatively very late in being differentiated in the embryos of Articulata; on the contrary, the appearance of the segments (the protozonites as they have been called) is in many cases the result of one of the first modifications of the blastoderm. These primitive segments unite in groups, and sometimes become soldered together, long before the differentiation of the nervous system; and when this system is developed, the number of its ganglia is not necessarily identical with that of the primitive segments. In the Annelida especially, the formation of the nervous system certainly sometimes follows very closely upon that of the segments, as in the embryos of Capitellus, for example; but most frequently it is much later. I do not, indeed, dispute that in many Annelida the origin and distribution of the nerves is in accordance with the rule of $\mathrm{M}$. 
de Quatrefages. However, we shall see that, in certain cases, not only the buccal segment, but also some of the following segments receive their nerves from the osophageal connectives, as in certain Aphroditea, some Hesionea, \&c. According to the theory of M. de Quatrefages, it would be necessary to regard the whole of these segments as constituting a multiannular buccal segment ; and yet each of them bears a pair of feet, and otherwise presents all the characters of an independent segment.

For my part I employ the name of antenna for all the appendages of the cephalic lobe; but where two of these appendages originate from the lower part of this lobe, at the same time acquiring special anatomical and physiological characters, I give them, like most other authors, the name of palpi. The modified cirri of the buccal segment and of the following segments are designated in this memoir as tentacular cirri.

Without wishing to enter into details here upon the structure of the feet in the Annelida, I desire to indicate what are the relations of the setæ to the tissues which surround them. Some authors regard them as enclosed in a sac which is only an invagination of the integuments; others think that they are formed in an internal follicle, and only secondarily arrive at the surface. This second opinion only is correct. In certain cases (in Hesione and others, for example) the whole bundle issues in a compact form through a single pedal aperture; but in others each seta has its own orifice. This is the case especially with the flabelliform bundles. The pore from which each seta issues is not previously formed, but is perforated by the seta itself. This is easy when the tissues of the worm are soft. But this is no longer the case when the Annelide is protected by a resistant cuticle, and when the seta, armed with hooks in various directions, seems fit to get itself entangled in the tissues and to produce serious lesions in them. In these cases the extremity of the young seta is surmounted by a small provisional apparatus terminated by an extremely sharp plate, destined to cut a free passage for the seta in the tissues, and to prevent tearing. The form of this piece varies greatly, like that of the seta and, especially, that of the hooks, the passage of which is to be effected without lesion of the neighbouring parts. I have already pointed out some examples of this singular arrangement, but they have been passed over without notice. Many others will be found in the course of this memoir*.

\section{Integuments and Muscular Apparatus.}

The integuments are composed of two layers:-one internal

* See especially under the head of Aphrodita aculeata, where this subject is treated in detail. 
and cellular (corium, Rathke, derme, Quatref.), corresponding with the subcuticular or chitinogenous layer of the other Articulata; the other extra-cellular, the cuticle (epidermis, Rathke \& Quatref.), sometimes very delicate, sometimes composed of a thick layer of chitine. The integuments have hitherto been studied with care only by M. Kölliker, to whom we are also indebted for several other excellent works on the histology of the Annelida, works all of which have unfortunately remained unknown to the author of the 'Histoire Naturelle des Annelés.'

The superficial layer deserves the name which has been given to it by M. Kölliker. From a histogenetic point of view it falls perfectly under the category of cuticular formations. The subcuticular layer (hypodermis, Weism.) which secretes it may often be denominated, as it is by M. Kölliker, an epithelium ; however, in most cases it is impossible to recognize the limits of its constituent cells. The nuclei seem rather to be scattered in it with considerable regularity in a continuous granular stratum, as has been seen by M. Baur in certain Arthropoda. Wherever the cuticle attains a certain thickness, it presents two systems of striæ at right angles (or more frequently about $70^{\circ}$ ), which have been already well observed by M. Kölliker*. The tubular pores (Porenkanäle of the Germans), when they exist, are distributed in lines congruent with these striæ. M. Kölliker has been struck by the distance which separates these pores from each other. Frequently, he says, not more than one of them corresponds with each subjacent cell; and he asks whether these apertures are really the homologues of the tubular pores (Porenkanäle) of the Arthropoda, or whether they may not rather be compared with apertures of the cutaneous glands, such as those discovered by M. Leydig in the Piscicola, or with the hairs of Insects and Crustacea. To this question I can reply positively that the two categories of pores exist in the Annelida. Those which serve for the discharge of certain secretions seem to exist in all species. Sometimes, especially in the large species, they attain a considerable diameter; but usually they are very wide apart. Sometimes, however, we find them brought together in groups or islets. The canalicular pores are much smaller and much closer together, and do not correspond with glands. They occur only in the species with a thick cuticle, and not even in all these. I shall describe some examples in detail, especially among the Eunicea. Wherever these very fine and approximated

* M. de Quatrefages, to whom these striæ are not unknown, sees in them the indication of two systems of fibres - an opinion which may be provisionally admissible in the case of certain worms. In any case the learned Academician with justice attributes to these striæ the iridisation of the surface of the body in many Annelides. 
tubular pores exist, we likewise find the large scattered glandular pores. This description applies not only to the external cuticle, but also to that of the pharynx when it attains a great thickness.

The subcuticular layer (the dermis of M. de Quatrefages) appears almost always to contain glandular follicles in all the regions, even in the cirri and antennæ. These follicles discharge themselves outwards through the glandular pores that I have just described. Some of them only secrete a thick liquid; others produce bundles of bacilli in their interior (I shall indicate these under the name of bacilliparous follicles); others, again, secrete granules.

The bibliography relating to the bacillar corpuscles of the Annelida is already rich. To M. Max Müller belongs the priority of the discovery of these organs, which he described and figured from the skin of two larval forms and from that of Chatopterus. They have since been observed by Dr. Strethill Wright in Spio, by M. F. Müller in Cherusca, by M. Danielssen in Scalibregma, \&c. I have myself devoted particular attention to them. I have indicated them in the Phyllodocea, in a Tomopteris (in concert with my friend Dr. Carpenter), in a Spharosyllis, in Spharodorum, and in the Palmyrida; and I have shown that, under certain circumstances, the contents of these follicles are suddenly discharged outwards. M. Kölliker has completely confirmed these observations. In the Phyllodocea M. Ehlers has likewise found the bacilliparous follicles, and ascribed to them the secretion of the mucosity. It is curious that observations so numerous as these should have entirely escaped the author of the ' Histoire Naturelle des Annelés.'

Certain families have their integuments literally crammed with bacilliparous follicles, even in the cirri and antennæ. This is the case especially in all the Spiodea and Ariciea and a great part of the Chatopterea. Their abundance is also remarkable in a great number of Phyllodocea and in some Hesionea. In the latter, especially, their grouping and their relation to the excretory pores are very remarkable. The function of these organs, indeed, is still quite problematical. I formerly compared them with the cells filled with aciculæ of the Turbellaria, and with the urticating organs of the Apneustic Mollusca, the Acalephæ, and Anthozoa; but this is pure hypothesis.

The tubular glands filled with spherical granules were first indicated by me in several Annelida. They sometimes attain a very large size, particularly in the Lycoridea; and in this case the glomerule formed by the interlacing of the glandular tubes was known even to the older writers, and regarded by them as a sac. M. de Quatrefages* was acquainted with one of the pas* Hist. Nat. des Annelés, tome i. p. 75. 
sages* in which I mentioned these organs, and cited an analogous observation of M. Keferstein; but by a singular mistake he makes us describe convolutions of blood-vessels, whilst we speak very positively of glandular coils. Such a confusion is hardly possible; for the passage relates to Nereids, in which the coils in question are colourless, whilst the vessels are of a fine red colour. M. Kölliker was the first to discover, in Spharodorum peripatus, that each coil of the glomerules contained in the spherical appendages opens outwards by a separate pore. This observation has just been repeated by M. R. Greef in Spharodorum Claparedii $†$.

\section{Muscular System.}

The muscles of the Annelida present extraordinary variations in their histological structure, as I shall have more than one occasion to show in the course of this memoir. Sometimes they are composed of fibres with parallel edges and entirely destitute of nuclei, sometimes, on the contrary, of fibre-cells furnished with large nuclei.

The existence in the Annelida of fibre-cells of a muscular nature has indeed been entirely denied by M. Schneider $\neq$. But although this naturalist may be right in the immense majority of cases, we shall see that this rule is liable to some exceptions (pharynx of certain Nereidea, tentacles of various Terebellea, \&c.). Sometimes the muscular fibre separates into two distinct layers (one axial, the other cortical), as M. Leydig was the first to remark $\S$. Nowhere is this structure so distinctly shown as in Nephthys. Lastly, in some Annelida, as M. de Quatrefages very justly indicates, the muscular system undergoes a remarkable simplification, in the loss of its fibrillar structure. Sometimes we find, in place of the muscles, nothing but a contractile protoplasm with nuclei dispersed through it. Of this we shall indicate some examples hereafter.

The 'Histoire Naturelle des Annelés' indicates between each segment a sort of tendinous raphe upon which the muscular fasciculi are inserted $\|$. These raphes have no existence. It is easy to ascertain, from longitudinal sections of Annelida, that the longitudinal fasciculi are continued without any interruption throughout the length of the worm. This has already been seen and described by De Blainville, Delle Chiaje, Rathke, Meckel, \&c.

* Beobacht. \&c. p. 52 .

+ See 'Annals' for July, vol. xx. p. 4 et seq.

+ "Ueber die Muskeln der Würmer, \&c.," Müller's Archiv, 1864, p. 590.

\$ "Ueber Phreoryctes Menkeanus," Archiv für mikrosk. Anat. Band i. p. 249.

II This notion, however, is revived from Cuvier. 
More or less complete muscular floors sometimes divide the perivisceral cavity into several chambers. M. de Quatrefages cites, as presenting this arrangement, the genus Polyophthalma and Terebella conchilega. Many other examples might be cited. Such are:- the Opheliea, the Polycirrida, many Terebellea, the Aphroditea, and the great majority of the Annelida Errantia, in which the perivisceral cavity is divided into three longitudinal chambers; the Glycerea, in which it is divided into two, \&c.

\section{Digestive Organs.}

For the different parts of the alimentary tube and, especially, of the trunk, M. de Quatrefages has endeavoured to establish a complete nomenclature, the opportuneness of which is at least contestable so long as the homologies upon which it is supposed to be founded are by no means demonstrated. Why, for example, in the Syllidea, should we give the name of dentary region of the trunk to an organ with glandulous walls, which constitutes no part of the trunk and contains no teeth*? The names employed by other authors - such as fleshy portion of the pharynx (Milne-Edw.), gizzard (Williams), and proventriculus (Ersted)appear to me to be very preferable. Are there any sufficient reasons for setting aside the names ventriculus and glands of the ventriculus, employed originally by Rathke for the Nereidea, and repeated by his successors? Is it really necessary to replace them by those of cesophagus and salivary glandst? I do not think so. Rathke's names were at least justified by analogy. One generally regards the salivary glands as more or less connected with the buccal cavity, whilst the glands in question often occur twenty or thirty segments behind the buccal segment.

In certain Annelida the posterior region of the intestine, following the biliary region, acquires a peculiar appearance. Its wall becomes filled with cells secreting curious concretions destined, no doubt, to be eliminated with the fæces. I designate this part of the intestine by the name of the urinary region, although, chemically, it does not seem to contain any uric acid $\ddagger$.

* M. de Quatrefages, it is true, enumerates a certain number of Syllidea armed with teeth in this region; but we shall find that in most cases, probably even in all, there is an error, and that the worms in question belong to totally different families.

† This name of salivary glands is indeed borrowed from Rud. Wagner, who employed it, as well as that of poison-glands, because he assumed that a canal starting from these glands penetrated to the extremity of the jaws. This canal does not exist. (See "Zur Anatomie von Nereis," Isis, 1834, p. 133.)

$¥$ I shall speak of this again in more detail in connexion with certain Syllidea. 


\section{Perivisceral Cavity and Circulatory System.}

We are indebted to M. de Quatrefages and Dr. Williams, but especially to the former, for a profound investigation of the perivisceral cavity and of the lymph which it contains. These naturalists, more than any one else, have pointed out the physiological importance of this liquid, which cannot be too highly estimated. Some details, only, require a slight rectification here. The perivisceral cavity is lined by a delicate membrane, which is not easily demonstrable, except in the larger speciesa membrane the discovery of which M. de Quatrefages ascribes to himself, and to which he gives the name of peritoneum. Had he thoroughly explored the works of Delle Chiaje and Rathke, he would have found in them both the membrane and the name. The structure of this peritoneum (tunica sierosa, tunica peritoneale of Delle Chiaje) is subject to considerable variations, as I shall show in the course of this memoir. At any rate, the perivisceral cavity is clothed, in some species, with vibratile cilia borne by the peritoneum. If I am not mistaken, Dr. Sharpey was the first to describe these, in Aphrodita; Dr. Williams then detected them in the branchiæ of the Glycera ; and I described them as occurring in the whole of the perivisceral cavity of the latter worms. They have also been seen in the Tomopteridea. M. de Quatrefages, who only notices in passing the observation of Dr. Williams, adds that this ciliary movement was long since known to him in a great number of Annelida, and that it will be met with in all the species, if we take the trouble to look for it. This opinion is not well founded. The immense majority of the Annelida present no ciliary movement in the perivisceral cavity, except at the entrance to the segmental organs. For my own part I am acquainted with the perivisceral ciliary coat only in the following groups:-in all the Aphroditea, Glycerea, and Polycirrida, in the Tomopteridea, and in a small and rather abnormal Terebella (T. vestita). It is a striking circumstance that all these Annelida, with the exception of the little Terebella and Aphrodita aculeata, are completely destitute of vessels. Now, of these two exceptions, one (the Aphrodita) is an animal with a rudimentary vascular system, helonging to a family which is otherwise entirely anangian; the other, the Terebella, belongs to a family which is generally vascular, but one tribe of which, that of the Polycirrida, is anangian. Considering these facts, I must regard the perivisceral ciliary movement as a function vicarial of the circulation in Annelida deprived of a true circulatory system.

The circulation of the Annelida has been most carefully described by M. de Quatrefages, who at the same time renders full 
justice to the beautiful investigations of M. Milne-Edwards. It is to be regretted that he has not shown the same favour to Rud. Wagner and Rathke. The distinction which he establishes between the arterial and venous currents appears to me to be very just in its principal features. The same view has been entertained by some authors; witness the name of nervarteria given by Delle Chiaje to the ventral vessel-that is to say, the aorta in the sense of M. de Quatrefages.

The existence of blood-corpuscles in the vessels of certain Annelida is now-a-days indubitable. M. de Quatrefages, in his 'Histoire Naturelle des Annelés,' admits three examples of this - the Glycera, Phoronis, and the Syllidea. The latter alone is of any value. Thus in the Glycerce the red eorpuscles belong: to the liquid of the perivisceral cavity; and as to Phoronis, that genus can hardly retain its place among the Annelida. But, without speaking of an old observation of Rud. Wagner with regard to a Terebella, which has, moreover, been confirmed by M. Kölliker, other examples may be cited. In the present memoir true blood-corpuscles will be found described in the Opheliea, the Cirratulea, and the Staurocephala.

\section{Respiratory Apparatus.}

M. de Quatrefages has made science actually go back as regards the structure of the organs of respiration. This is the weakest part of his book-weak in the introduction, weak in the general remarks on each family. The branchiæ, in the opinion of the honourable Academician, have a proper structure, which enables them to be always distinguished. "These organs," he says, "are characterized by a single canal, at and from which afferent and efferent vessels arrive and depart. This canal, the proper walls of which are sometimes visible and sometimes indistinct, is surrounded by a diaphanous substance which seems to be produced by the thickening of the dermis. In this substance are hollowed out ampulliform lacunæ more or less developed, and always destitute of proper walls. The whole is surrounded by an extremely fine epidermis, which presents no appreciable structure. Finally, this epidermis is beset with vibratile cilia...... At the end of a variable time the branchia contracts, although no muscular fibres can be discovered in it. The ampullæ empty themselves, so as sometimes to disappear entirely. The blood flows through the central canal of the branchia, and, on arriving at the base of the organ, passes into the efferent vessel. In this movement of return it necessarily meets the venous blood, and cannot but become mixed with a certain quantity of blood which has not undergone the action of the air." 
In contrast to this radically false description, let us see how the circulation is effected in the normal branchia of an Annelide. There cannot be in a regular way any mixture of arterial and venous blood; in fact the artery travels as far as the extremity of the branchia, where it bends round to return as a vein. The vein and the artery are exactly parallel to each other. Through the whole length of the branchia these two vessels are put in communication by a double series of vascular loops, which pass into the subcuticular layer, and which are subjected with the greatest facility to the action of the water charged with oxygen, through the very thin cuticle. As to the contraction of the supposed ampullæ, there is nothing of the kind. Sone genera, such as the Terebella and the Telethusa, for example, certainly present rhythmical contractions of the whole branchia, but not of the vessels themselves. This fact, however, is exceptional. The family Serpulea alone presents in the structure of its branchiæ a distant resemblance to the description of M. de Quatrefages. In these Annelides the artery is continued directly into the vein at the base of the branchiæ, and from their point of union starts a single vessel, which penetrates into the branchia and sends a cæcum into each branch of it. But M. de Quatrefages describes in the secondary branches of the branchiæ of the Serpulea all his apparatus of ampullæ, of which not the least trace exists. The excal vessel does not present any ramification; it is simply cylindrical and contractile, as described by MM. Grube and Kölliker*. In these branchiæ the blood exhibits an alternating circulatory movement; but this is the only exceptiont; in all the other families the branchial circulation constantly takes place in the same direction. Cæcal vessels with alternating circulation are met with also in the tentacles of the Spiodea, Amphictenea, and Pherusea, and in $a$ part of the so-called branchial filaments of the Cirratulea; but the latter organs are not respiratory (unless perhaps lymphatic).

How could M. de Quatrefages commit an error so manifest and so frequently repeated? This is easily explained. The branchiæ are in general not cylindrical, but slightly compressed. Now, in the position which they must naturally take under the microscope, the artery exactly conceals the vein, and one might

* M. Milne-Edwards, ignoring these observations, erroneously attributes to the Tubicolous Annelida lymphatic branchiæ exclusively (Leçons sur l'Anat. et la Physiol. tome ii. p. 103).

+ I think I have a right to speak thus categorically. Of the twenty-six families of Annelida admitted by M. de Quatrefages, I have studied twentyfive anatomically, by the dissection of numerous species or individuals. As to the twenty-sixth, that of the Hermellea (Sabellaria), it is too nearly related to the Amphictenea and Terebellea to allow us to suppose that it differs much from them. 
suppose that there is only one vessel. As to the supposed ampullæ, these are the projections of the vascular loops. It is only necessary to turn the branchiæ a little, in order to dissipate the first illusion. M. de Quatrefages has allowed himself to be deceived by the first examination, as Pallas did long since.

But this error is not permissible at the present day. It is already thirty years since M. Grube settled it. It is thirty years since, in his anatomy of Pleione carunculata, he indicated the occurrence, in the Terebella and Arenicola, of this deceptive appearance, which led Pallas into an error which M. de Quatrefages has now reproduced. He showed that a less superficial examination led to the recognition of the artery, the vein, and the loops which unite them. No microscopist warned of the danger will go and throw himself upon it. Many modern observers have described and figured the duplicity of the axial vessel of the branchia,-amongst these M. Grube and M. Schmarda in the Cirratulea, M. Schmarda in Nephthys, Dr. Johnston in the Nerina, M. Keferstein in the Spiodea, and myself in the Spiodea and Eunicea. At a still earlier period, Delle Chiaje* described in detail in Eunice and Diopatra the artery and the vein passing spirally side by sidet in the interior of the branchia, at the same time emitting numerous vascular branches $\ddagger$. But all these observations have remained dead letters to the author of the ' Histoire Naturelle des Annelés.'

I have stated that all Annelida present the typical structure of the branchix, except the Serpulea. I must, however, add that one family presents a remarkable simplification of this organization. This is the family Spiodea. Throughout this family the branchiæ only contain the two principal vessels, the artery and the vein; the lateral loops are wanting.

The lymphatic branchiæ will form the subject of a special investigation, in the Annelida which present them (Sigalionida, Dasybranchi, Glycera). 1836.

* Istituzioni di Anatomia comparata, 2a ediz. tome ii. p. 76. Naples,

+ This description is very correct, as we shall see hereafter in connexion with Diopatra neapolitana (Delle Chiaje).

† M. Milne-Edwards, that excellent observer, has likewise recognized the duplicity of the branchial vessel; but, in his 'Leçons sur la Physiol. et l'Anat. des Animaux' (tome iii. p. 217), he has modestly put his own observations into the shade, in order to set off those of M. de Quatrefages and proclaim the existence of a cæcal vessel with ampulliform diverticula. The observations of M. de Quatrefages upon the branchiæ of the Glycerce and Polydora, the only ones that he cites, appeared to him decisive. M. de Quatrefages has been unfortunate in the selection of his examples: the Polydore, with their simple branchial loop, cannot produce the illusion of the ampulliform diverticula; and the Glycera have no vessels at all! 


\section{Reproductive Apparatus.}

The reproductive apparatus of the Annelida has hitherto been very imperfectly known. Numerous works have indeed thrown fresh light upon the educatory organs, known, since Dr. Williams wrote upon them, by the name of segmental organs. But as regards the sexual glands our knowledge has made but little progress for the last thirty or forty years. This memoir will, I hope, make known these organs in a satisfactory manner in a great number of species. M. Ehlers limits himself to saying that the sexual glands may be referred to a single fundamental type-namely, that of a coherent cellular mass, engendered on the inner surface of a part of the wall of the body, or on the dissepiments. This statement is true in many cases. M. Krohn saw the ovules make their appearance as a sort of epithelium on the surface of the dissepiments in Alciope; and I have myself made perfectly similar observations on Protula Dysteri. This rule cannot, however, be regarded as general. The sexual glands often present themselves under perfectly different conditions.

The observations of M. de Quatrefages relate chiefly to the Nereida and Eunicea. He has seen the sexual elements make their appearance in these Annelida in a glandular organ extended beneath the abdominal nervous chain. This description is at any rate very inaccurate, as will be seen hereafter on reading the exposition of the singular construction of the sexual glands in various Lycoridea \&c.

The distribution and structure of the sexual glands in the Annelida is subject to numerous variations, which will be illustrated by a multitude of examples in the course of this memoir. Nevertheless the following form may be regarded as the most generally diffused among the Annelida :-The sexual glands form more or less complex racemes or networks of cords, the axes of which are occupied by sanguiferous branches, which are often contractile. The sexual elements in course of growth form ruffs all round the vascular axes, and become developed at the expense of a layer of nuclei contiguous to the vessel. In the females the ovules are often in immediate contiguity to each other in the ovary; but sometimes (in Owenia, Delle Chiaje, and some species of Polynö̈) each of them is enclosed in a special ovisac. In all cases the ova, when arrived at maturity, detach themselves from the ovary, either immediately, or mediately by the rupture of the ovisac. For the most part the spermatozoids likewise detach themselves from the testes to float freely in the perivisceral cavity.

This fundamental form undoubtedly sometimes undergoes important modifications-for example, to produce the singular sexual tissue of the Nereidea or the floating testes of the DasyAnn. \& Mag. N. Hist. Ser. 3. Vol. xx. 
branchi, which will be described in the special portion of the present memoir. The formation of the ova in the Terebellea and Serpulea departs from it still more widely; but throughout we shall find a cellular tissue, either fixed or composed of floating elements, in the midst of which the sexual elements are developed.

The sexual glands have indeed been known for a long time in certain Annelida; but these early observations have been in part forgotten. Thus whilst Pallas* erroneously represented the ova of Aphrodita as originating in the liquid of the perivisceral cavity, G. R. Treviranus $\dagger$ and Delle Chiaje $\ddagger$ were well acquainted with the true ovaries at the base of the feet in these worms. Delle Chiaje also indicates the ovaries of the Pherusea, Hermione, Polyodonta, Parthenopeia, Diopatra, Nephthys, Telamon, \&c. He knew very well that the ova are formed in the ovaries, but that, when arrived at maturity, they detach themselves therefrom, and float freely in the perivisceral cavity $\$$. Even the existence of a blood-vessel in the axis of the sexual glands was not unknown to some observers. Thus Delle Chiaje $\|$ indicates the axial vessels of the ovarian racemes in Siphonostomum and the Stylarioïda; M. Stannius 9 has made analogous observations on Amphinome rostrata; M. Grube has seen the ovules originate round vessels in the Arenicola**; and M. Schmarda †† describes the axial vessel in the ovaries of Euphrosyne. All these observations appear to have met with little credit, but they are none the less perfectly correct.

Frequently, it is true, organs have been wrongly regarded as sexual glands. For example, wherever Rathke believed he saw testes in the Nereides, Pectinaria, \&c. he was mistaken $\ddagger \ddagger$. All authors have been mistaken with regard to the testes of the Arenicola. The segmental organs of the Terebellea have also had the fate of being taken for ovaries by nearly everybody from Cuvier to MM. Milne-Edwards, Grube, Quatrefages, and even Sars. Dr. Williams, of course, did not remain behind, as this

* Miscellanea Zoologica, p. 91.

† Zeitschrift für Physiol. Bd. iii. p. 165. Darmstart, 1829.

— Descrizione e Notomia, \&c. tom. v. p. 59.

§ Istituzioni di Anat. Comp. ed. 2. tom. ii. p. 158.

II Descrizione, \&c. tom. iii. p. 78.

वा Isis, 1831, pp. 989-990.

** Zur Anatomie der Kiemenwürmer, 1838, p. 16.

†† Neue wirbellose Thiere, Bd. ii. p. 137.

If Rathke himself, however, recognized these errors as soon as he perceived that the Arenicola, the Ammotrypance, \&c. had the sexes separate. The segmental organs, which he had previously regarded as testes, then became to him muciparous glands. (See "Beiträge zur Fauna Norwegens," Nova Acta, \&c. 1843, tom. xx. p. 201.) 
was too favourable to his theory. The mistake appears to have been caused in some cases by the presence of ovules in these organs, which are probably concerned in oviposition*.

Since the investigations of Dr. Williams, the segmental organs have given rise to much controversy. Most recently, M. Ehlers regards them as apparatus destined to conduct outward the mature sexual elements; and this opinion is certainly correct. Besides the facts cited in its support by that anatomist, others will be found in the course of the present memoir. Nevertheless this is not the only function of the segmental organs. Thus they exist in the anterior segments of many Annelida in which the ovules and spermatozoids never penetrate into that region. Their wall is often glandular, and histologically comparable with the elernents of the kidney in the Gasteropoda (Amphictenea, Pherusea). Therefore I hardly doubt that these organs also play an excrementitial part. We know also that in the Oligochæta only a small number of these segmental organs are modified for the purpose of conducting outward the sexual elements, whilst the rest incontestably fulfil other functions. In the Polychrta, likewise, it is only a part of the segmental organs that take the part of an efferent generative apparatus.

The older authors, who were acquainted at least with the external apertures of the segmental organs, such as Treviranus (who describes them in Aphrodita) and Delle Chiaje (who assumes their existence in all Annelida, and mentions them in many species), attributed a very different function to these organs. They regarded them as serving for the introduction of water into the perivisceral cavity. This opinion can no longer be maintained. The direction of the ciliary movement in the calibre of the tube is opposed to it, as also the circumstance that the inner orifice of the segmental organ seems to be wanting in some instances; at least I believe I have ascertained this to be the case in some Capitellea.

M. de Quatrefages, who has never been able to see a segmental organ, attributes to M. Ehlers and myself the honour of having contributed most to the extension of Dr. Williams's

* It is chiefly to M. de Quatrefages that we owe the recent demonstration of the diœecious nature of the immense majority of the Annelida. We must, however, not forget that before him Delle Chiaje maintained this diœciousness in opposition to all his contemporaries, and that in the most formal manner. He knew that the generative organs present the same form in both sexes. According to his observations, the males are less abundant than the females. (See Descrizione e Notomia, \&c., tom. iii. p. 100). Baster and Pallas, however, appear to have been the first to ascertain positively the diœciousness of an Annelide, Aphrodita aculeata. (See Natuurkundige Uitspanningen, \&c., Deel ii. p. 68, edit. 1817, and Miscellanea Zoologica, 1766 , p. 90.) 
discovery. He ought, I think, to have eited in the first place the mane of $\mathrm{M}$. Hering, who is nowhere mentioned in the "Histoine Naturelle des Annelles." However this may be, the honourable Academieian reproaebes us, and especially myself, with having said a great deal and drawn but little. I do not think I deserve this reproach, as the segmental organs of the Annelida, being very simple modifieations of a very constant type, may be easily deseribed without having reeourse to the pencil. Moreaver, without speaking of the works of M. Fhlers and myself, M. de Quatreflages might have found segmental organs deseribed and figured by M. Keferstein, in Cirratulus filiformis (Keferst.), Copitella (Notomustus) nubieunda (Kef.), Terebella gelatimosa (Kef.), and Syllis oblonga (Kef.). Nevertheless, in order to satisfy the desire expressed by M. de Quatrefages, figures relating to the segmental organs of various Annelida will be found in the plates following this memoir,

It is, moreover, indubitable that there are Annelida destitute of segmental organs, or at least in which these organs are reduced to simple apertures in the wall of the body.

\section{Nerroous Bystem.}

It is undoubtedly to M. de Quatrefages and M. Leydig that we owe the finest investigations upon the nervous system of the Annelida; the former has oceupied bimself especially with the exterior form of this system, and the latter with its histology. The "Histoine Naturelle des Anneles' omits all historieal details upon this subject; but if we go back to the earlier works of the author, we shall find a concise and well. executed summary of the previous researches*. It is more to be regretted that it takes no notice of the labours of recent histologists, MM. Leydig, Mettenheimer, \&ce. On the whole we find in the portions of this memoir relating to the nervous system a confirmation of the investigations of M. de Quatrefages. On some points, bowever, I must differ from bim. Lastly, there is an important chapter upon which I have hardly a right to pronounce judgment. In nearly all the famillies M. de Quatretages has been fortunate enough to detect a stomato-gastrie nervous

* See "Etudes sur les types inférieurs de Pembranehement des Annelés. Mémoire sur le systeme nerveux des Annelides," Ann. Sei. Nat. tome xiv, p. 332, 1850. No doulbt this summary presents some gaps. We rogret especially to see no mention in it of the investigations of $G$. R. Treviranus upon the nervaus system of Aploroditas for this observer was already well acquainted not only with the ventral chain and the nerves which originate from it, but silso with the ganglis of rainforcement at the base of the feet. 
systen, similar to that of the Hirudinea. I confess that I have been unable to discover it; but $I$ feel that this negative result is of no great weight in so difficult an investigation. I am, however, astonished to find that so many other observers have had no better fortune than myself in perfectly similar endeavours.

M. Leydig has described in the Hirudinea a structure of the nervous centres which he characterizes as follicular*; and he opposes it to that of the Annelida, according to his own researches on the Oligochrta and those of M. de Quatrefages on the Polychrta. This distinction cannot be made so absolute. Certain Annelida Polychrta have a follicular nervous system as well as the Hirudinea. This is the case, for example, in Nereilepas candata \&c., as I shall show hereafter. Others present nothing of the kind.

The structure of the nervous system varies, however, astonishingly in the series of the Annelida; the distribution of the nerve-cells especially is subject to a multitude of modifications which we shall point out in particular cases. In the ventral chain, the cells belong chiefly to the ventral surface and the sides, as M. Leydig has already noticed. The existence of large tubular fibres on the dorsal surface of the nervous chain, so general in the Oligochæta, is restricted in the Polychrta to a small number of families (Capitellea, Ariciea, Spiodea, Syllidea, Eunicea), and apparently even only to certain representatives of these families.

The terminations of the nerves in the Annelida have hitherto been studied only by myself, M. Keferstein, and M. Kölliker. Numerous observations on this subject will be found in the present memoir. All these terminations seem to be in relation to the function of touch. The nervous expansion of the organs of sight and hearing + is in reality still very imperfectly known, even in Aleiope, notwithstanding the investigations of M. Leydig. In connexion with this, I cannot abstain from mentioning an opinion of J. Müller's, which has fallen into oblivion. We owe to that great physiologist $\ddagger$ an excellent figure of the central nervous system and of the eyes of the Nereides, a figure to which his successors have added nothing very positive. In his opinion, the organ which we now eall the crystalline is not a dioptric medium; he denies its transparency, and regards it as a terminal inflation of the optic nerve. Although the trans-

* The observations of M. Baudelot upon Clepsine (Ann. Sci. Nat. tome iii. 1865, p. 126) are a complete confirmation of this.

† When M. Vietor Carus (Handbueh der Zoologie, p. 430) aseribes auditory capsules to the majority of the Annelida, he deceives himself very greatly. The existence of these organs is peculiar to a very restrietert number of species.

‡ "Mémoire sur la structure des yeux chez les Mollusques Gastếropodes et quelques Annélides," Ann. Sei. Nat. tome xxii. 1831, p. 23. 
parency of the crystalline is incontestable in many cases, Müller's opinion as to the functional value of this organ must not be rejected. The eyes of the Nereides and of most of the Annelida appear to be destitute of any apparatus of accommodation. If therefore we assume that the perceptive elements are lodged between the granules of the pigment, only objects placed at a determinate and perfectly fixed distance can project their images upon the surface of this choroid pigment. The vision of the animal would, in this case, necessarily be very restricted. This difficulty disappears if we seek in the crystalline at once a refractive body and a perceptive organ, nearly as we seem compelled to admit with regard to the crystalline cones of the Arthropoda. The image projected at various depths in the crystalline by objects placed at variable distances would then always be formed in a sensitive layer.

\section{Regeneration of Mutilated Parts.}

The observations of Bonnet upon the regeneration of mutilated parts in the Earthworms, confirmed by Lyonnet, Réaumur, Dugès, \&c., were hesitatingly doubted by Vandelius* and Bosc $\dagger$, and more recently and positively by Dr. Williams $\ddagger$, M. Vogt $\S$, and others. We must therefore be thankful to those who, like Dr. Baird $\|$, have brought to light certain early observations, or, like M. de Quatrefages $\uparrow$, have corroborated and confirmed them by fresh experiments.

The reproduction of mutilated parts in the Annelida is incontestable. A great number of these worms, perhaps all, can even reproduce the anterior region including the head. Among

* "Dominici Vandelii philosophi ac medici dissertationes tres. De Aponi Thermis, de nonnullis insectis terrestribus, et Zoophytis marinis, et de Vermium terræ reproductione, atque Tania canis. Padua, 1758," pp. 98147. This work, which seems to have been forgotten, is nevertheless the production of a good observer. In very careful experiments, repeated for two successive years, he did not succeed in seeing mutilated Earthworms reproduce their anterior extremity. He, nevertheless, prudently concludes that these experiments require to be made with extreme care, and does not accuse Réaumur of having deceived himself. We know that Dugès afterwards likewise began by obtaining negative results, but that subsequent experiments succeeded with him completely. The regeneration of the anterior part takes place, in fact, only when the number of segments removed is not too great.

† Histoire Naturelle des Vers, tome i. pp, 128 \& 215.

+ " Report on the British Annelides," Report of the British Association, 18551 , p. 247.

\$ Vorlesungen über nützliche und schädliche, verkannte und verläumdete Thiere. Liepzig, 1864, p. 91.

|| Johnston's Catalogue of British non-parasitical Worms. Appendix.

I Ann. Sci. Nat. tome ii. 1814, p. 100 ; Hist. Nat. des Annelés, tome i. p. 126. 
recent authors, M. de Quatrefages has afresh demonstrated this fact in Eunice, and Dalyell followed step by step the reproduction of a head and branchiæ by the posterior extremity of a Sabella*. For my own part I have frequently met with marine Annelida (Eteone, Nephthys, \&c.) which had undoubtedly reproduced their anterior region. The regenerated part is distinguished by a lighter colour and smaller diameter. The aspect of these worms recalls that of the Heteronereides; so much do the two regions strike the observer by their different appearance. One might think them two sections of different worms united together. An interesting question presents itself in connexion with this : in a worm cut transversely does the posterior part always reproduce a number of segments equal to that of the anterior part which has been suppressed in front of it? This seems probable. At least I have found an Eteone which had reproduced an anterior section of nearly fifty segments. The head is no doubt the part first formed; then the new segments are produced successively at the point of union of the old and new parts. This, however, requires to be supported by positive observations.

\section{Geographical distribution of Annelida.}

This subject, which is still imperfectly known, has only been approached in a positive manner by M. de Quatrefages; but the data which that naturalist had at his disposal were insufficient to admit of his drawing any very eertain conclusions. There is, however, one point upon which I must contradict him, namely the extreme localization of the faunas. For example, M. de Quatrefages does not admit that the Mediterranean and the Ocean can be inhabited by the same species. It sometimes happens that he founds specific distinctions solely upon this circumstance of different habitat, although authors have been unable to establish any morphological difference between these supposed species. He insists especially upon the impossibility of a littoral species supporting conditions of life so different as those resulting from the presence or absence of tides. At Naples, however, I kept littoral Annelida for months in captivity, and found that the best means of making them thrive is to deprive them of water for several hours every day, so as to allow the mud to become oxygenated. These new conditions did not prevent their living very well and depositing their eggs.

No doubt, in a general way, the fauna of the Mediterranean

* The powers of the Creator displayed in the Creation, \&c. vol. ii. 1853, p. 231. 
is very distinct from that of the ocean; but several species appear to be positively common to the two seas. M. de Quatrefages, moreover, is perpetually untrue to his own theory; we. find him uniting even very distinct species, one belonging to the Mediterranean and the other to the Atlantic or even to the Arctic seas*.

Faunistic works alone will throw any real light upon the geographical distribution of the Annelida. It is therefore to be desired that we may witness the multiplication of such investigations as those of M. Malmgren $†$ upon the Annelida Polychæta of Spitzbergen, Greenland, Iceland, and Scandinavia. It is undoubtedly the best work of its kind that we possess. It has the advantage, in most cases, of being enriched with bathymetrical data. The absence of particulars of this nature is a defect in most memoirs on Annelida. It is especially a gap which I regret I am unable to fill up in this fauna of the Bay of Naples. M. Malmgren seems to lead us to hope for the early publication of a work on the Annelida dredged off the coasts of Spitzbergen at a depth of 1400 fathoms (famnar) by M. Carl Chydenius. An accurate knowledge of Annelida living under such conditions would be of great scientific interest.

\section{Classification.}

It is gratifying to see that we are every day approaching more and more towards a natural classification of the Annelida. The families now established are for the most part well founded. The discovery of types so new as to necessitate the formation of new families becomes rarer every day. For my part I shall propose no new family name. I know that on this point there is a difference of opinion among naturalists. MM. Kinberg and Malmgren have recently considerably increased the number of families. But this augmentation is only apparent. Certain very natural families of Savigny's have been divided into several by M. Kinberg; but that naturalist has been careful to preserve Savigny's sections as divisions of a higher rank, under the name of orders. This is a slight displacement of the terms of the taxonomic hierarchy, the importance of which is not very great. For my own part I take, to a certain extent, the same view as M. Kinberg; but I regard as tribes what he calls fami-

* Thus he unites Polynoë maculata (Grube) and P. fasciculosa (Gr.) of the Mediterranean with P. cirrata (Fab.) from Greenland, Amphis tubicola (Gr.) of the Mediterranean with Nereis tubicola (O. F. Müll.) from the coast of Denmark, Lysidice Valentina (Sav.) of the Mediterranean with L. rufa (Gosse) of the British coasts, Nereis cultrifera (Gr.) of the Mediterranean with $N$. bilineata (Johnst.), \&c. \&c.

† “Nordiske Hafs-Annulater," in GEfvers. af K. Vet.-Akad. Förhandl. 1865, Nos. 1, 2 \& 5; 'Annulata Polychæta Spetsbergiæ, Grœnlandiæ, Islandiæ et Scandinaviæ hactenus cognitæ,' Helsingfors, 1867. 
lies, and I retain for his orders the name of families given to them by Savigny and his successors. The entire suppression of the orders in M. Kinberg's sense, and retention only of greatly multiplied families, according to M. Malmgren's practice, is, in my opinion, to be regretted.

Certain families of recent creation seem to me to be excellentfor example, that of the Spharodorida (Mlmgr.). It is also with pleasure that I find M. Malmgren reverting to the opinion of Oken and of MM. von Siebold and Max Müller, and placing the Sternaspida among the Annelida. This author is astonished that, in the year 1865, M. de Quatrefages, in assigning to Sternaspis a place among the Gephyrea, should still mistake the head of these animals for the tail, without taking any notice of the beautiful anatomical investigations of MM. Krohn and Max Müller. I share in M. Malmgren's astonishment, especially as neither Bianchi (Janus Plancus), Ranzani, nor Della Chiaje had fallen into the error of Oken and Otto, now corroborated by the authority of M. de Quatrefages.

It is less easy to come to an understanding upon the genera than upon the families in the class of Annelida. Their number has been increased in very considerable proportions both by M. Kinberg and by M. Malmgren. I am far from adopting the views of those naturalists, whose works have nevertheless been of great use to me, as will be seen from nearly every page of the present memoir. The species investigated by them have been examined with extreme care, if not as to their anatomical construction, at least in their external zoological characters. I think, however, that among the characters considered by them to be generic, many have only a specific value, or may even serve at most to distinguish the varieties of a single species. This is the case especially with the denticulations of the setæ, as I shall show by more than one example in the present memoir. I have nevertheless retained a great part of the generic groups of MM. Kinberg and Malmgren, but frequently only according them a subgeneric value. As a matter of course, however, among the genera established by these authors there are some excellent ones which every one will accept without hesitation.

XLV.-On the Campodeæ, a Family of Thysanura. By Dr. Fr. Meinert*.

Since J. C. Fabricius first drew the attention of entomologists to the systematic importance of the organs of the mouth in In-

* Translated from 'Naturhistorisk Tidsskrift,' ser. 3. vol. iii. p. 400. Copenhagen 1865 . The Danish original is accompanied by a plate, from which the woodcuts are copied. 


\section{$2 \mathrm{BHL}$ Biodiversity Heritage Library}

Claparède, René-Édouard. 1867. "XLIV.-On the structure of the Annelida, including a critical examination of the most recent works on this class of worms." The Annals and magazine of natural history; zoology, botany, and geology 20, 337-361.

View This Item Online: https://www.biodiversitylibrary.org/item/72234

Permalink: https://www.biodiversitylibrary.org/partpdf/61276

\section{Holding Institution}

University of Toronto - Gerstein Science Information Centre

\section{Sponsored by}

University of Toronto

\section{Copyright \& Reuse}

Copyright Status: NOT_IN_COPYRIGHT

This document was created from content at the Biodiversity Heritage Library, the world's largest open access digital library for biodiversity literature and archives. Visit BHL at https://www.biodiversitylibrary.org. 